\title{
Do farmers and conservationists perceive landscape changes differently?
} $\underline{\text { Noémi Ujházy }}^{1,2}, \underline{\text { Zsolt Molnár }}^{3,4}, \underline{\text { Ákos Bede-Fazekas }}^{3,4},{ }^{\dagger}$ Mária Ottilia Szabó ${ }^{1}$ and Marianna Biróó $^{4}$

\begin{abstract}
Broader understanding of stakeholders' perceptions of landscape changes is needed to cope with global environmental challenges locally. In this study, farmers' and conservationists'-researchers' perceptions of landscape changes were compared by analyzing interviews conducted in the Danube-Tisza Interfluve region of Hungary through a combined quantitative and qualitative approach. Perceptions concerning the trends of changes (increasing or decreasing), as well as evaluations (positive and negative) of 40 different landscape elements were analyzed. The quantitative analysis consisted of landscape elements of different native and alien plant and animal species, natural habitats, and types of land use. For a qualitative analysis, one landscape element, the tussock sedge beds, a type of wetland habitat, was chosen. According to the quantitative analysis, the two groups held similar views on trends. However, their evaluations differed substantially. The most significant differences appeared between the two groups in cases where land use and biodiversity goals were in competition, e.g., abandonment and non-native plantations. Changes causing both decline of biodiversity and the fading of the cultural landscapes were seen similarly negatively by the two groups, e.g., disappearance of lakes, spread of invasive plants, expansion of wild boar. However, quantitative analysis also showed that conservationists-researchers had higher consensus, while farmers were much more diverse in their evaluations. Qualitative analysis explored the reasons for these differences. Although conservationists-researchers shared eco-centric values, farmers evaluated landscape changes heterogeneously based on individual constellations of economic interest, cultural values, and their sense of responsibility for nature. Our study, with the combined application of quantitative and qualitative analyses, provides new understandings of both between-group and within-group differences and similarities of farmers' and conservationists'-researchers' landscape change perceptions.
\end{abstract}

Key Words: consensus; environmental knowledge; environmental value; perception; stakeholder; wetland

\section{INTRODUCTION}

Exploring tensions among various forms of environmental knowledge and values is of rising importance for environmental sustainability (Berkes 2004, Díaz et al. 2015, Chan et al. 2016, Raymond et al. 2019). Perception is a key term for gaining and producing knowledge about the environment, through socially bonded and value-laden activities (Ingold 2000, Bennett 2016). In this manner, it challenges the assumption of the body-mind and nature-culture dualism, as well as resonating with the ideas of constructed boundaries of nature and culture (Latour 1993, Descola and Pálsson 1996, Münster et al. 2012). The classical geographical concept of landscape is essential for studying the nature-culture continuum and its dynamic temporalities (Ingold 2000). Thus, landscapes can be understood as transforming social-ecological systems (Bieling 2013) in which changes are affected by both societal and environmental drivers (Bürgi et al. 2017). Landscapes also have political and cultural significance, as they embody the contested and debated histories of human interaction with the environment (Olwig 1996, Widgren 2012). Discourses of nature change over time (Antrop 2005, Buijs et al. 2006), and through transforming the social-ecological systems the baseline of preference is also shifting (Selman 2012, Soga and Gaston 2018). Based on their worldviews, personal experiences, or relationships to nature, multiple stakeholders can perceive landscape changes differently (Bennett 2016). Therefore, to foster participation and navigate trade-offs of landscape changes it is highly relevant to explore the differences of perceptions between various stakeholder groups (Benjamin et al. 2007, GarcíaLlorente et al. 2008, Plieninger and Bieling 2012, Sayer et al. 2013, Molnár et al. 2016). We analyze perceptions of landscape changes of two stakeholder groups, farmers and conservationistsresearchers of the Danube-Tisza Interfluve, Hungary.

The studied region is one of the most dynamic parts of the country (Csorba et al. 2018. et al. 2018) and has undergone many changes over the centuries (Biró et al. 2013a). After the Ottoman occupation the area was mostly depopulated, but since the 18th century private farms started to be established in the scarcely populated countryside. During the 19th century, shifting sand dunes were stopped by new tree plantations, and grasslands were converted to arable lands, vineyards, and orchards (Biró et al. 2015a). Extensive wetland areas neighboring the sand regions began to be drained on a large scale during the early decades of the 20th century (Ujházy and Biró 2018) and by the middle of 20th century, the Duna-Tisza Interfluve became a densely inhabited mosaic of cultural landscape elements and remnants of natural vegetation. Under socialism, drainage of the wetlands continued and farm collectivization and conversion to larger scale mechanized farming took place. The Kiskunság National Park was formed to protect natural wetlands and sand vegetation in 1975 (Iványosi Szabó 2015). By the 1980s, the area experienced a drastic decline in groundwater, caused by climatic and other anthropogenic factors (Kohán and Szalai 2014). This process resulted in a severe decrease of wetlands and further land use changes (Biró et al. 2013a, Biró et al. 2015a), highly concerning to local stakeholders, even up to current times (Kelemen 2013, Blanka et al. 2017). The abandonment of farms and less productive areas had already begun in the socialist period, but land abandonment peaked after postsocialist transformations (Pándi et al. 2014). After Hungary's accession to the European Union (2004) the trend of abandonment in many areas reversed,

${ }^{1}$ Eötvös Loránd University, Department of Environmental and Landscape Geography, Budapest, Hungary, ${ }^{2}$ Research Centre for Astronomy and Earth Sciences, Geographical Institute, Budapest, Hungary, ${ }^{3}$ Centre for Ecological Research, Institute of Ecology and Botany, Vácrátót, Hungary, ${ }^{4}$ Centre for Ecological Research, GINOP Sustainable Ecosystems Group, Tihany, Hungary 
and agriculture started to intensify. Natural protected areas also expanded during this period with the establishment of the Natura 2000 network (Mihók et al. 2017). Moreover, wetland restoration took place on several protected sites (Sipos 2015). These regional trends coincided with some major traits of globalizing landscapes, the drastic loss of high-biodiversity cultural landscapes due to simultaneous trends of abandonment and intensification on one hand, and the apparent influence of nature conservation on local landscape changes on the other hand (Plieninger and Bieling 2012, Kuemmerle et al. 2016, Bürgi et al. 2017). The case of the DanubeTisza Interfluve can provide insights into the discussion of these globally important trends.

Several aspects and processes of landscape change perceptions have been addressed by previous studies analyzing interviews with stakeholders. We differentiate two main aspects: first, the processes of local landscape trends (Dallimer et al. 2009, Herrmann et al. 2014, Mashi and Shuaibu 2018), including their drivers (Mbow et al. 2008, Bezák and Mitchley 2014, Ariti et al. 2015, Bürgi et al. 2017); and second, the social values, uses, and attitudes associated with landscape elements and their changes (Bardsley and Edwards-Jones 2007, Byg et al. 2017). Many studies have investigated the perception of various processes of landscapes: wetland transformations (Sherren and Verstraten 2013, Byg et al. 2017), growing human-wildlife conflicts (Storie and Bell 2017), the invasion of non-native species (Bardsley and Edwards-Jones 2007, García-Llorente et al. 2008, Rai et al. 2012), intensification (Carr and Tait 1991, Junge et al. 2011), or the abandonment, regrowth (Benjamin et al. 2007, Bieling 2013, Ruskule et al. 2013, Stelling et al. 2017), and restoration of habitats (Hobbs 2016, Byg et al. 2017). What is common in these studies is that they all focus on rearranging the borderline of the nature-culture continuum. In our research, we cover the two aspects of trends and evaluations, as well as all the various processes, together.

Farmers' perceptions have special importance in perception studies for several reasons, and their role as agents of changes and stewards of landscapes is increasingly recognized (Kelemen et al. 2013, Raymond et al. 2016). Farmers' local knowledge of the transforming socio-natural world can be crucially important in dealing with climate change adaptation and sustainability transformations (Nakashima et al. 2012). Through agrienvironmental schemes, farmers are becoming directly involved in biodiversity conservation throughout Europe (de Snoo et al. 2013) and by using extensive traditional farming practices they can contribute to the high biodiversity of cultural landscapes (Varga and Molnár 2014, Babai et al. 2015, Vadász et al. 2016, Ispán et al. 2018, Biró et al. 2019). Hence, a deeper understanding of farmers' knowledge and values is especially important (Ahnström et al. 2009, de Snoo et al. 2013, Kelemen et al. 2013). Farmers perceive landscape changes intertwined with their family histories and economic struggles in a changing socioeconomic climate because of a long connection to the land (Schwartz 2006, Aistara 2009, Gray 2014). Many examples from Central and Eastern European countries confirm this by examining the effects of transformation into socialism, postsocialist liberalization and privatization, and accession to the European Union on landscape processes (Schwartz 2006, Aistra 2009, Dorondel 2012). How farmers view landscape changes is also connected to how farmers identify themselves in these changing socio-political contexts. A number of studies deal with the important role of utility, cultivation, and productivity in their identity as a good farmer (Burgess et al. 2000, Burton 2004, Boonstra et al. 2011). The tidiness of landscape and control of natural processes could be a symbol of sovereignty (Schwartz 2006). Although these preferences of farmers do not align with the aims of conservation, many studies have observed that farmers do not always prefer cultivation over biodiversity and they have rich and very heterogeneous environmental values (Herzon and Mikk 2007, Junge et al. 2011, Kelemen et al. 2013). One reason for this heterogeneity of farmers' perception is that farmers tend to have more tacit knowledge, in contrast to the more codified, expert knowledge of conservationists (Morris 2010). Concerning the social values of nature, compared to the intangible values of farmers, conservationists value the biodiversity more independently of contexts (Kenter et al. 2019, Raymond et al. 2019).

Although many studies emphasize the need for comparing different stakeholders' perceptions of landscape changes (e.g., Sayer et al. 2013, Raymond et al. 2019), systematic comparisons of farmers and conservationists-researchers are scarce (Carr and Tait 1991, Natori and Chenoweth 2008). Furthermore, only a minority of landscape change perception studies apply both quantitative and qualitative analysis of interviews (e.g., Carr and Tait 1991, Bardsley and Edwards-Jones 2007, Ruskule et al. 2013, Ariti et al. 2015). This lack of mixed methodologies is surprising because the integration of systematic comparability of quantitative and qualitative approaches to a greater depth could be highly advantageous in social-environmental research (Muhar et al. 2018). In addition, the value-heterogeneity of farmers, although highlighted by many, has not yet been examined comparatively with a mixed methodology.

Using a comparative mixed-method approach we aimed to fill these gaps by examining the following questions:

1. Do farmers and conservationists-researchers see the trends of the landscape changes differently?

2. Do farmers and conservationists-researchers value landscape elements and their changes differently?

3. Do farmers and conservationists-researchers differ in their value-heterogeneity?

\section{METHODS}

\section{Description of the study site}

Our study is located in the Danube-Tisza Interfluve region of central Hungary $\left(46^{\circ} 41^{\prime}-46^{\circ} 58^{\prime} \mathrm{N} ; 19^{\circ} 14^{\prime}-19^{\circ} 32^{\prime} \mathrm{E} ; 22 \times 30 \mathrm{~km}\right)$. The area (80-120 $\mathrm{m}$ a.s.1.) is a quaternary alluvial fan of the Danube River covered with coarse and fine-grained sand (Pásztor et al. 2018). The yearly precipitation is $500-550 \mathrm{~mm}$, and the mean annual temperature is $10.5-11^{\circ} \mathrm{C}$ (Bihari et al. 2018). The natural vegetation is a forest-steppe mosaic with dry sand habitats and wetlands (fens, alkaline marshes and wet meadows), whose fragments form the base of the Kiskunság National Park (Biró et al. 2015a).

The landscape of the study area has undergone great changes over the past two centuries (Biró et al. 2013a). Nowadays it is characterized by a fine-scale mosaic of afforested areas, arable 
lands, grasslands, orchards, vineyards, and wetlands. The study area is located across 11 settlements with populations of approximately $850-6500$. The formerly widespread small-scale farming system is currently in decline, as are populations on the outskirts (Pándi et al. 2014). As one of the most dynamically changing regions in Hungary and even in Europe nowadays, abandonment, farming intensification, and afforestation take place concurrently (Biró et al. 2013a, b, Kuemmerle et al. 2016, Csorba et al. 2018).

\section{Data collection}

Interviews were conducted with 57 farmers (born between 1930 and 1973, on average in 1949; the majority with secondary school degrees) and 17 conservationists-researchers (born between 1944 and 1976, on average in 1963, with higher education or tertiary degrees). Both fields are traditionally dominated by men: $84 \%$ of the interviewed farmers were men and $16 \%$ women; $88 \%$ of the interviewed conservationists-researchers were men and $12 \%$ women. We selected farmers using snowball sampling (Newing 2010), starting with local intellectuals, e.g., veterinarians, park rangers, teachers, and office workers interested in local history, who recommended farmers considered knowledgeable within the community and preferably living or having lived on farms in different parts of the villages' territory. The group of conservationists-researchers was made up of former or current employees of NGOs $(\mathrm{N}=3)$ and national parks $(\mathrm{N}=12)$, as well as experts in ecology $(\mathrm{N}=5)$ who have studied the territory for more than 15 years. All of them were involved in conservationoriented research in the area. Before the interviews, informed consent was obtained. Interviews consisted of a series of structured interview questions and unstructured interview sections for all of the 40 landscape elements under investigation (Newing 2010). At the start of interviews, we began by establishing the territories within the study area that the interviewees knew best and the period of that familiarity, asking questions about their biography, profession, and experiences. Afterward, our questions pertained to this particular region and time period.

We asked the same two structured questions about each of the landscape elements:

1. Trend: How has the area/distribution/abundance of the given landscape element changed? (much less / slightly less / no change / slightly more / much more);

2. Opinion: What is your opinion of this trend? (negative / neutral / positive).

Structured questions were followed by the unstructured interview section about other issues regarding the landscape elements, such as their location and abundance; the reasons, processes, and timescales related to the changes; and personal experiences or arguments underlying the opinions. Inquiry into landscape elements was aided by 40 postcard-size pictures, which were given to the interviewees in a random order. Showing them to the interviewees helped to identify the landscape elements and evoke experiences about them, while also maintaining the flow of interviews. Interviews lasted an average of 1-1.5 hours; they were voice recorded, and detailed notes have been kept of the conversations.

\section{Examined landscape elements}

We used a mixed method approach to address our research questions. The two structured interview questions were analyzed quantitatively for 40 different landscape elements and we chose one landscape element to analyze qualitatively for this article.

40 different landscape elements: quantitative analysis

Based on previous studies, we selected 40 different landscape elements on the basis of their relevance to nature conservation, the defining role they play in recent landscape transformation, and their visibility and recognizability in the landscape by farmers (Biró et al. 2013a, Ujházy and Biró 2013). Data on statistical or scientific trends were not available for the majority of the landscape elements, except for certain habitats (Biró et al. 2018) and bird species (Szép et al. 2012), as well as habitat and land cover changes (Biró et al. 2013a) on the regional or national level.

The 40 landscape elements under investigation were:

- Land use types: arable land, vineyard, orchard, old field, channel, farm, hay meadow, pasture;

- Domestic animals: cattle, sheep, domestic goose;

- Alien herbaceous plants: Asclepias syriaca, Ambrosia artemisiifoia, Solidago spp.;

- Alien shrubs, trees, and plantations: Robinia pseudoacacia (planted and invasive), Ailanthus altissima (invasive), Elaeagnus angustifolia (invasive), Populus spp. (plantations), Pinus spp. (plantations), Populus nigra "Italica" (near farms and countryside roads);

- Natural habitats and plants: (A) wetlands: lakes, wet meadows, tussock sedge beds, saline land, reed beds (Phragmites australis), reeds (thin, on grasslands), Salix cinerea; (B) Nonwetlands: sand dunes, Stipa borysthenica, Juniperus communis;

- Native animals: European pond turtle (Emys orbicularis), Common Lapwing (Vanellus vanellus), fish (in general), frogs (in general), Barn Swallow (Hirundo rustica), Common Buzzard (Buteo buteo), roe deer (Capreolus capreolus), wild boar (Sus scrofa); and

- Climate (precipitation): rain, snow.

Tussock sedge beds (tussock): qualitative analysis

To complement the quantitative analysis based on the 40 landscape elements listed above, we chose to analyze qualitatively the perception of one landscape element, the tussock sedge beds. This particular wetland vegetation type was selected for qualitative analysis during the data collection phase because of the ambivalent perceptions of tussock sedge beds. The tussock sedge community is formed mainly by bunches of different sedge species (mostly Carex elata), surrounded by surfaces temporarily covered by water. Tussocks, because of their specific vertical structure, give rise to diverse microhabitats for various protected plant and animal species (Lájer et al. 2011). Thus, they are of high relevance for nature conservation. Territories with tussocky habitats experienced a huge loss in this area over the past centuries because of the extensive drainage of wetlands (Biró 2015, Biró et al. 2015b). Although they are not the most valuable grass type for 
Table 1. Applied statistical methods and their connections to our research questions concerning between-group differences and withingroup variability.

\begin{tabular}{|c|c|c|c|c|c|}
\hline Method & $\begin{array}{c}\text { Differences } \\
\text { between groups }\end{array}$ & $\begin{array}{l}\text { Variability within } \\
\text { groups }\end{array}$ & Data type & Data entities & Questions \\
\hline Mann-Whitney U Test & $\times$ & & $\begin{array}{l}\text { trend } \\
+ \\
\text { evaluations }\end{array}$ & $\begin{array}{l}\text { landscape } \\
\text { elements }\end{array}$ & $\begin{array}{l}\text { Are the groups significantly different in their } \\
\text { perceptions? }\end{array}$ \\
\hline $\begin{array}{l}\text { Nonmetric } \\
\text { Multidimensional Scaling } \\
\text { (NMDS) }\end{array}$ & $\begin{array}{l}\quad \times \\
\text { (distance and } \\
\text { overlap) }\end{array}$ & $\begin{array}{c}\times \\
\text { (spread of points) }\end{array}$ & $\begin{array}{l}\text { trend } \\
+ \\
\text { evaluations }\end{array}$ & interviewees & $\begin{array}{c}\text { Are the same group of interviewees more similar } \\
\text { to each other than to the other group? }\end{array}$ \\
\hline Consensus Measure (Cns) & & $x$ & $\begin{array}{l}\text { trend } \\
+ \\
\text { evaluations }\end{array}$ & $\begin{array}{l}\text { groups } \times \\
\text { landscape } \\
\text { elements }\end{array}$ & $\begin{array}{l}\text { Is there a consensus within the group in their } \\
\text { perceptions? }\end{array}$ \\
\hline $\begin{array}{l}\text { Spearman's Rank } \\
\text { Correlation }\end{array}$ & $\begin{array}{l}\quad \times \\
\text { (difference of } \\
\text { correlation } \\
\text { values) }\end{array}$ & $\begin{array}{l}\quad \times \\
\text { (correlation } \\
\text { value) }\end{array}$ & trend-opinion & $\begin{array}{l}\text { groups } \times \\
\text { landscape } \\
\text { elements }\end{array}$ & $\begin{array}{l}\text { Is there a strong connection between a perceived } \\
\text { trend and opinion? } \\
\text { Are the directions of the correlation the same or } \\
\text { the opposite between the two groups? }\end{array}$ \\
\hline
\end{tabular}

foraging, historical data shows that this habitat was regularly grazed in the past (Biró et al. 2019).

\section{Quantitative data analysis}

\section{Data types}

We used Microsoft Excel sheets to input the answers that conformed to ordinal, Likert scale categories (Newing 2010) derived from the two basic interview questions:

1. Trend: How has the area/distribution/abundance of the given landscape element changed? (much less / slightly less / no change / slightly more / much more); and

2. Opinion: What is your opinion of this trend? (negative / neutral / positive).

Based on these two values, we calculated a third, evaluation:

3. Evaluation: calculated value $=$ trend $\times$ opinion (negative $/$ neutral / positive).

This calculation added new data about whether the evaluation of a specific landscape element was rather positive (with positive opinions about growth and negative about decrease), neutral, or negative (with negative opinions about growth and positive about decrease). Detailed notes from the interviews were also entered into the datasheets, and they were used to interpret the quantitative results.

\section{Statistical analysis}

Statistical analysis of the data and plotting of the results were carried out in R Statistical Software (R Core Team 2017) using the packages vegan (Oksanen et al. 2016), Hmisc (Harrell 2018), scales (Wickham 2017), tidyr (Wickham and Henry 2018), and ggplot2 (Wickham 2009). Four statistical approaches were applied to explore the between-group differences and withingroup variability of the two groups (Table 1):

1. Mann-Whitney U Test (Wilcoxon rank-sum test), a nonparametric test of the null hypothesis that the two groups belong to the same population, was calculated on the trends and evaluations and the 40 landscape elements.
2. Nonmetric Multidimensional Scaling (NMDS) was calculated on trends and evaluations. NMDS in two dimensions was performed using the additive inverse of Spearman's rank correlation coefficient (Spearman 1904) rescaled from the $[-1 ; 1]$ to the $[0 ; 1]$ interval as a dissimilarity measure. Grouping ordination ellipses were drawn based on standard deviation of point scores, where the direction of the ellipse's major axis was defined by the weighted correlation.

3. Consensus Measure (Cns), developed by Tastle and Wierman (2007), was used to analyze Likert scale data calculated for the 40 landscape elements based on the results of both groups regarding their opinions and evaluations of trends.

4. Spearman's Rank Correlation (Spearman 1904) between trend and opinion was calculated on the 40 landscape elements.

\section{Qualitative analysis}

One selected wetland landscape element, the tussock sedge beds, was analyzed with qualitative methods (Newing 2010, Saldaña 2015). Transcribed interview segments were coded, using QDA Miner Lite software. We applied a multistep method for coding and analysis (Saldaña 2015, Castleberry and Nolen 2018, Kennedy and Thornburg 2018):

1. Open coding: an open coding applied to 16 interviews helped to identify themes (we tried out both in vivo, topical, and structural codes).

2. Selection of codes: codes were selected inductively based on the observations of the open coding, the strength and gaps of the quantitative analysis, and deductively informed by the theoretical approaches in literature.

3. First coding cycle: we applied structural and topical codes (1. Process, 2. Cause, 3. Location, 4. Valuation and use, 5. Experience, 6. Relation to other landscape elements) and meanwhile we took analytic memos. 
Fig. 1. Perceived trends of landscape elements by farmers and conservationists-researchers (Mann-Whitney test, $*<$ $0.05 ; * *<0.01 ; * * *<0.001)$.
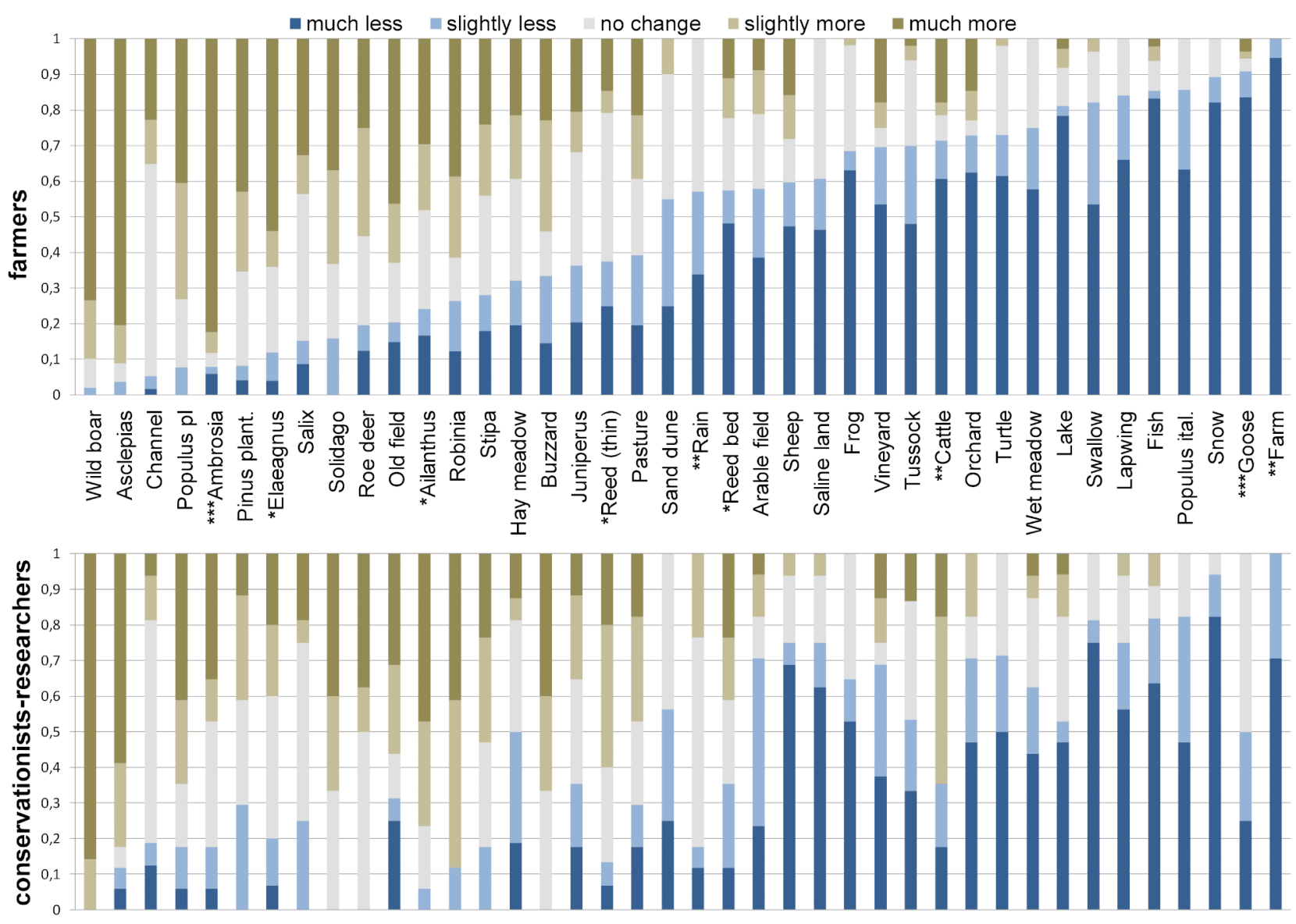

4. Disassembling: the first cycle's codes were revisited and inductively divided into different categories.

5. Interpretation 1: after reviewing the list of subcategories we decided to develop a quantification and next coding cycle.

6. Quantification: for the 2. and 4. codes we systematically counted some common answers (2. Cause: water/use; 4. Valuation and use: use/water/biodiversity). We put this new data together with the quantitative data from structured interview questions.

7. Second coding cycle: we coded all the mentions of nature conservation/natural park. Interview segments referring to social context and value conflicts were coded too.

8. Interpretation 2: Results of previous analysis steps were interpreted together.

\section{QUANTITATIVE RESULTS}

\section{Perceptions of landscape change trends}

Comparison of trend perceptions

The most visible changes for farmers were the drastic decline of farms and farmland species (swallow, domestic geese, or Populus nigra "Italica"), as well as decreases in snowfall, wetland habitats, and animal species. They also experienced the growth of game species (especially wild boar) and the expansion of abandoned fields, invasive species, growing tree plantations, and shrub encroachment (Fig. 1). Conservationists-researchers perceived landscape elements' trends similarly. There was no significant difference in the case of tussock sedge beds either. In only one quarter (11) of the landscape elements was there a significant difference between the two groups (Fig. 1). With most of the landscape elements, the two groups agreed on the direction of changes; differences mostly appeared in their perception of the intensity of changes. The conservationists-researchers perceived a less intensive decline in terms of the farms, geese, and cattle, and less intensive growth of some invasive species. In terms of trend values, farmers and conservationists-researchers were not considerably separate on the NMDS (distance between the ellipses being 0.115 ; Fig. 2a). Also, they were similarly scattered (area of the ellipses being 0.034 and 0.04, respectively; Fig. 2a).

\section{Consensus analysis of trend perceptions}

The average consensus values (Cns) on all of the trends showed a modest consensus within both groups (farmers $0.57 \pm 0.15$, conservationists-researchers $0.62 \pm 0.18$ ). The consensus was higher within the conservationist-researcher group in the case of nearly three quarters of the landscape elements (29). The consensus was low $(\mathrm{Cns}<0.5)$ in 15 cases within the farmer group, 
but only in 7 cases among the conservationists-researchers. For both groups the consensus value was lower than 0.5 in the case of vineyards, old fields, cattle, and reed beds, and both had high consensus $(>0.8)$ about the decrease in farms and snowfall (Table A1.1).

Fig. 2. Nonmetric Multidimensional Scaling (NMDS) ordination plots for (A) the perceived trends in landscape elements and (B) their evaluations.

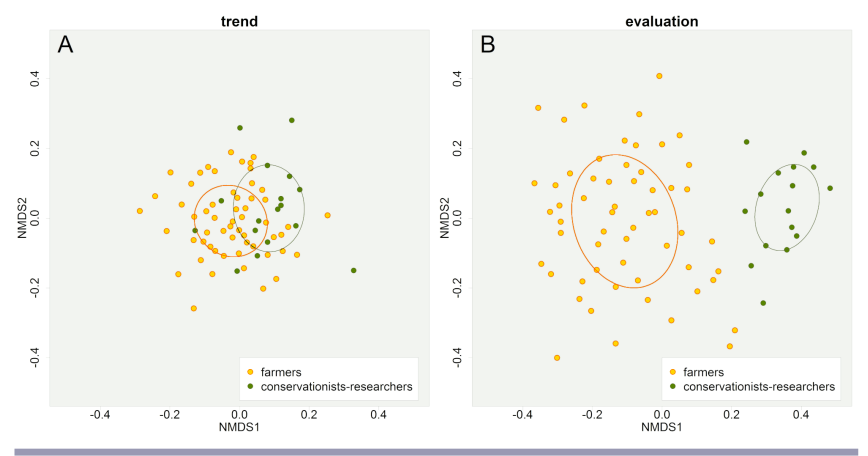

\section{Opinions on perceived trends}

Concerning opinions on trends in landscape elements, both groups were dissatisfied with the perceived changes. While conservationists-researchers had more negative and positive opinions than the farmers, the neutral opinions were more frequent within the farmer group. When changes in the 40 elements were analyzed separately, farmers assessed only 3 in a mostly positive way, 18 neutrally, and 19 negatively. For conservationists-researchers, the results were 5 positively, 13 neutrally, and 22 negatively. As far as overall opinion data for the farmers, $18 \%$ of answers were positive, $29 \%$ neutral, and $54 \%$ negative. For the conservationists-researchers, $22 \%$ were positive, $15 \%$ neutral, and $64 \%$ negative.

Combinations of the perceived trends and related opinions are shown in Fig. 3. From this figure, it is apparent that, opposed to the polarized negative or positive responses of the conservationists-researchers, farmers had more neutral reactions, independent of their perception of the trend. From this figure it is also apparent that the answers tended to characterize tussocks as mostly decreasing; and this reduction was valued negatively by the group of conservationists-researchers, while farmers viewed it positively, negatively, and neutrally. Fewer answers indicated stagnation or growth in the tussocks. On the contrary, growth was valued mostly positively by conservationists-researchers and negatively by farmers. Evaluation values and correlations between trend-opinion answers in the following chapters quantify these kinds of connections between the trend and opinion answers.

\section{Evaluations of landscape elements}

\section{Comparison of the evaluations}

Unproductive landscape elements connected to abandonment had negative values for farmers (invasive species, wild boar, old fields, and sand dunes), while other more productive landscape elements were positively valued (rain, farms, lakes, and domestic and wetland animals; Fig. 4). Farmers and conservationistsresearchers differed considerably in their evaluation scores of landscape changes, calculated and based upon their trend and opinion answers. Regarding more than half of the examined landscape elements (22), there was a significant difference in their evaluations (Fig. 4). In 10 cases, we found strongly significant differences between the two groups: for example, in case of tree plantations (Robinia, Populus, and Pinus plantation), abandonment (old fields), and arable fields, in addition to the case of tussock sedge beds. On the NMDS plot, farmers and conservationists-researchers were quite separate in their evaluations (the distance between the ellipses being 0.468), and farmers were much more scattered (area of ellipses being 0.09 and 0.035, respectively) (Fig. 2b).

\section{Consensus analysis of the evaluations}

The average of the consensus values indicated a moderate consensus within both groups concerning the evaluations of all landscape elements (farmers: $0.56 \pm 0.12$, conservationistsresearchers: $0.67 \pm 0.28$ ), although conservationists-researchers had slightly stronger agreements on average. The conservationistresearcher group had higher consensus in the case of 27 landscape elements. They had full consensus $(\mathrm{Cns}=1)$ in the case of 12 examined landscape elements, e.g., most of the perceptions of invasive plants and wild boar being fully negative, while those of wetland animals being fully positive. By contrast, no full consensus was shown within the farmer group (Table A1.1, Fig. 4). The weakest consensus among farmers concerned the tussock sedge beds (0.28), whereas the consensus value for this same element by conservationists-researchers was close to one (0.85).

\section{Correlation of trend perceptions and opinions}

On average, trend-opinion correlation was stronger within the conservationist-researcher group than within the farmer group. The average of absolute correlations along the 40 landscape elements was $0.46 \pm 0.25$ for farmers and $0.62 \pm 0.30$ for the conservationist-researcher group. Robinia and Pinus plantation, arable fields, and sheep were mostly positively valued by farmers and negatively by conservationists-researchers; whereas old fields and sand dunes were valued negatively by farmers and positively by conservationists-researchers (Fig. 5). The weakest correlation among farmers also concerned the tussock sedge beds $(0.03)$, whereas the correlation for conservationists-researchers was close to one (0.92), which supports the results of the consensus analysis.

Nonplanted alien herbaceous plants and trees had negative correlation values in both groups, but the correlation was stronger within the conservationist-researcher group. Nonetheless, there was a greater difference between the two groups concerning species used in afforestation. These were positively valued by farmers, contrary to the negative evaluation of other non-native species. Animals native to wetland habitats and precipitation (rain and snow) showed a strong, positive correlation in both groups. Pastures, cattle, and hay meadows had similarly positive correlation values among both groups; however, in the case of more intensive land uses like orchards and vineyards, there were more differences between them.

\section{QUALITATIVE RESULTS}

\section{Trend perceptions of the tussock sedge beds}

Processes of changes

Most of the farmers and the conservationists-researchers observed a decrease in the area with tussocks. Among the conservationists-researchers, however, trends perceived as 
Fig. 3. Combinations of perceived trends and opinions of all the 40 landscape elements.

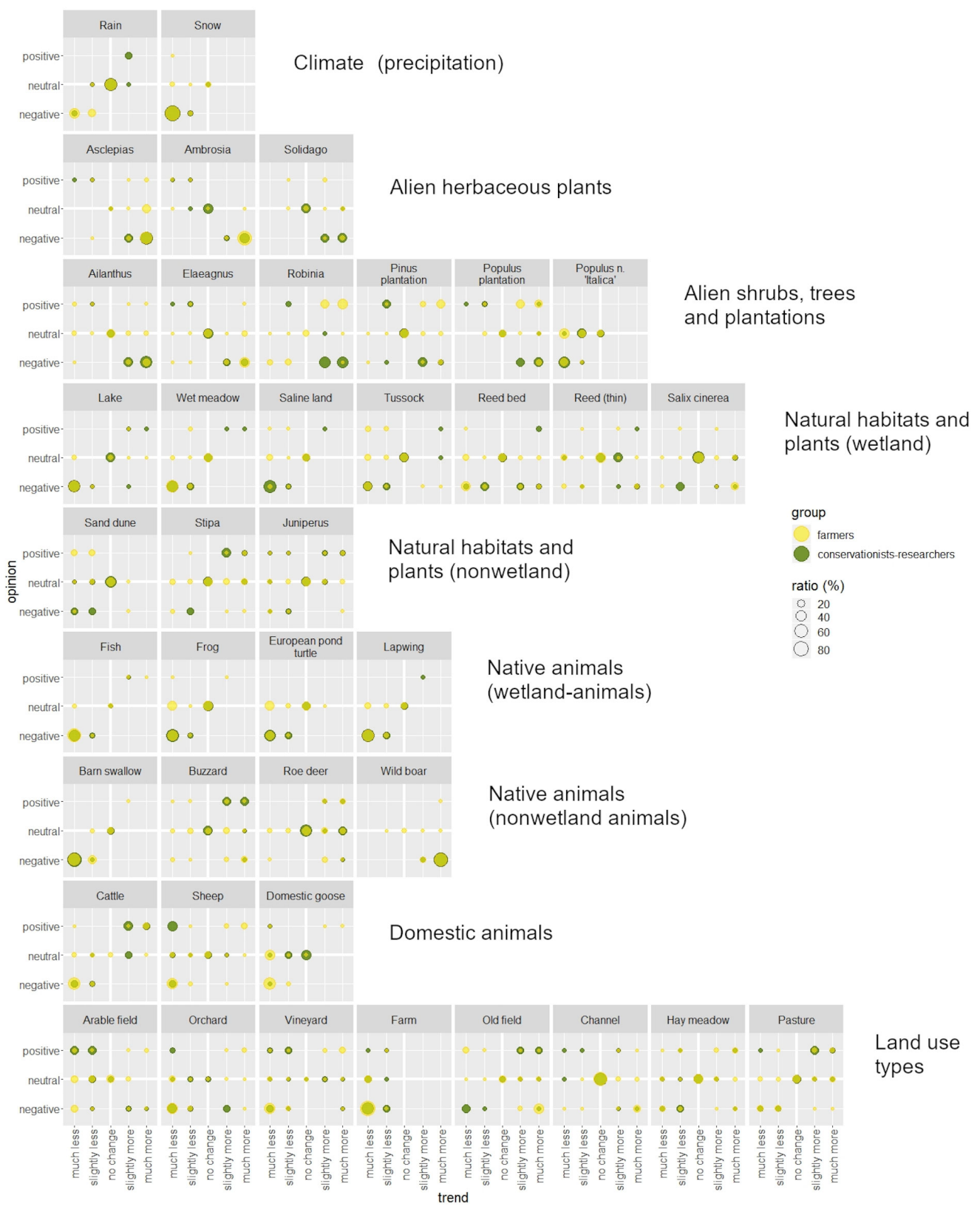

stagnating or growing were slightly more frequent. "Well, there were already few of these tussocks. You know that the channel was dug during the 60s," said one conservationist-researcher. Many conservationists-researchers perceived a qualitative change: "I have seen tussock sedge in a lot of places ... but it is not functioning as a tussock sedge community ... it still has some elements of its vegetation, but it is disappearing." Conservationists-researchers also more frequently emphasized the territorial differences at a regional scale: "There are one or two plots that were conserved by the artificial water level control of Lake Kolon, but all of the others disappeared from the territory."
Drivers of changes

The most commonly perceived driver of change for both groups was the availability of water. This included water managementinduced changes, drainage channels, changes in precipitation and climate, or a decrease in groundwater ( $81 \%$ of farmers, $53 \%$ of conservationists-researchers mentioned it). Interestingly, farmers were more concerned with changes induced by human land use (37\% of farmers, $18 \%$ of conservationists-researchers) such as grazing, mowing, direct clearing with machines, and burning. In many cases, farmers mentioned lack of water, changing uses or clearing as sequential drivers of the transformation: "The tussocks disappeared all because there is no precipitation, there 
Fig. 4. Evaluation of landscape elements by farmers and conservationists-researchers, based on the calculation of perceived trends and opinions: evaluation $=$ trend $\times$ opinion $($ Mann-Whitney test, $*<0.05 ; * *<0.01 ; * * *<0.001)$.
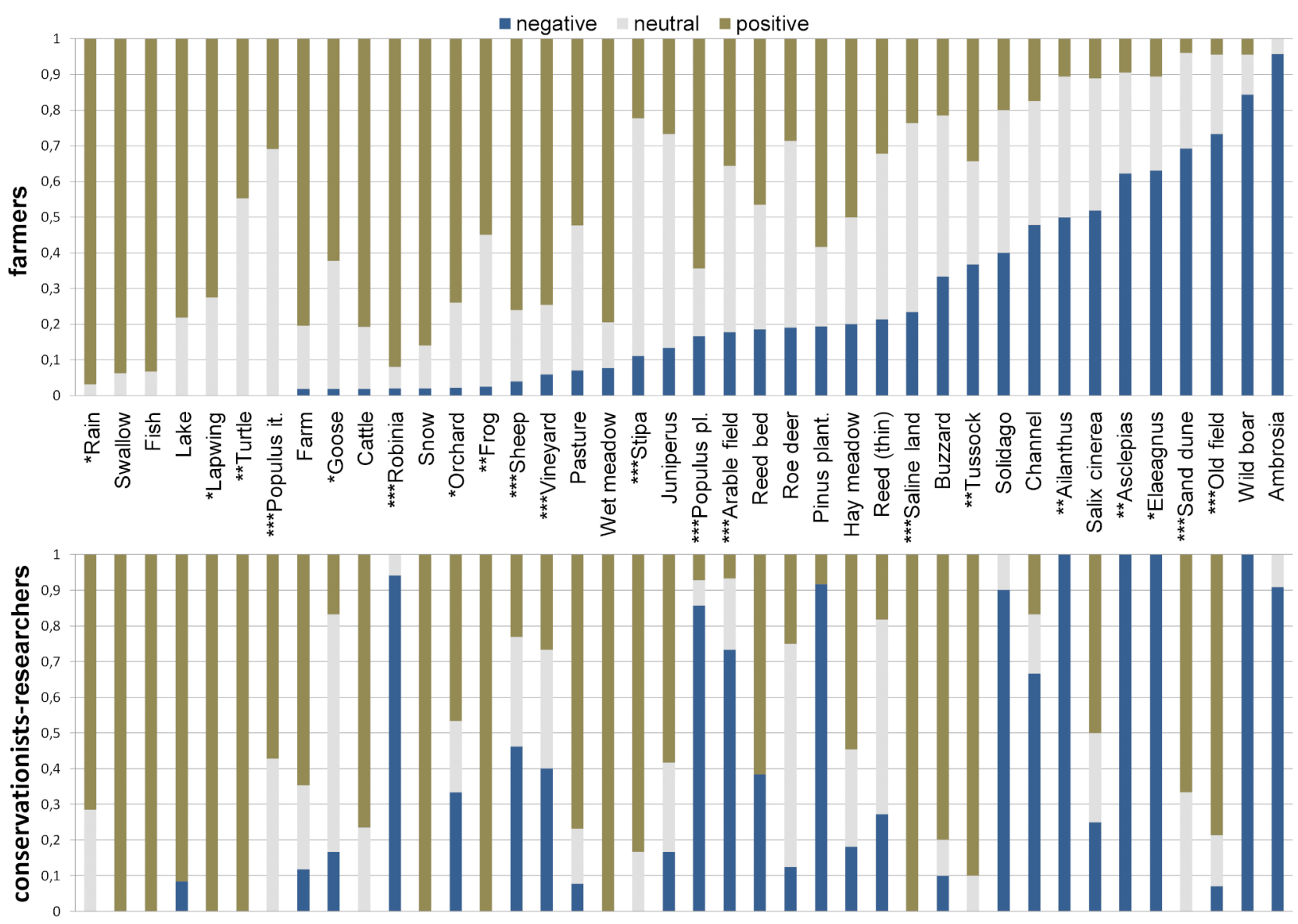

is no water. The farmers who had lands like that disked it [levelling the ground]. Now they could go over it with machines ... they plough it, and now it's a beautiful grassland, so they graze it."

\section{Evaluations of changes in the tussock sedge beds}

Values and uses of tussock sedge beds

Changes in the tussocky vegetation were evaluated very differently by the two groups. For conservationists-researchers, the loss of tussocks was consistently negatively valued. "There is a significant decline in the wetland habitats, and this is absolutely negative." Farmers, however, held very mixed opinions about the changes. Many farmers emphasized that the tussocks are not important for them, and they had neutral opinions about it. Limited usefulness played a salient role in the farmers' valuations $(72 \%$ of farmers): "Even the animals don't like it. It is so sharp that if a man grasps it, plucks at it a bit, it could easily cut his hand, too. It is a very useless plant. Because these tussocks are raised and uneven, they are very hard to strip, whether by machine or hand."

However, in spite the above mentioned "uselessness" of tussocks, grazing, mowing, and egg collecting were commonly mentioned uses of the tussocky areas by farmers. These practices show how they engaged with the territories, as an elderly farmer couple remembered: "We were picking wild duck eggs (laughing). Yes, it was so, I remember. Wild duck used to nest in places like this back in my childhood." The woman added, "We were grazing the cattle and walking on these [tussocks]." The man continued, "We were grazing the cows, cooperating beautifully with the children." The women replied, "Living on the farm was indeed wonderful!"

A couple of farmers also mentioned that these tussocky wetland territories were good habitats for birds, but wildlife had a special importance for only four farmers when evaluating these processes: "There's much less, and I consider it bad, because it served as a hiding place for animals."

Even if the tussock itself was not highly valued by farmers, its disappearance has huge relevance for them because it indicates a lack of water: "Well, if I look at the precipitation, it is bad. If I look at the fact that there are no bushes [tussocks], then it's better." Many farmers emphasized the essential importance of water for other uses and for wildlife alike: "There are few there, and the water's gone there, too ... There is no water. Here everything, all the wildlife, is determined by water. Water determines cattle breeding, the sheep, the farm, the tree, and the sand dune alike. If they take away water, there is no wildlife. Just look around. There are no birds. How many were there when there was lots of water here?" 
Fig. 5. Spearman correlation between perceived trends and opinions of farmers and conservationists-researchers. In the case of positive correlation, opinions of reductions are negative, and opinions of increases are positive; whereas in the case of negative correlation, decreases are valued positively, and increases negatively. Along the diagonal axis from lower left to upper right, farmers and conservationists-researchers share similar reactions to landscape changes. In the upper left corner are phenomena more positively valued by conservationists-researchers, while the lower right corner features landscape elements more positively valued by farmers.

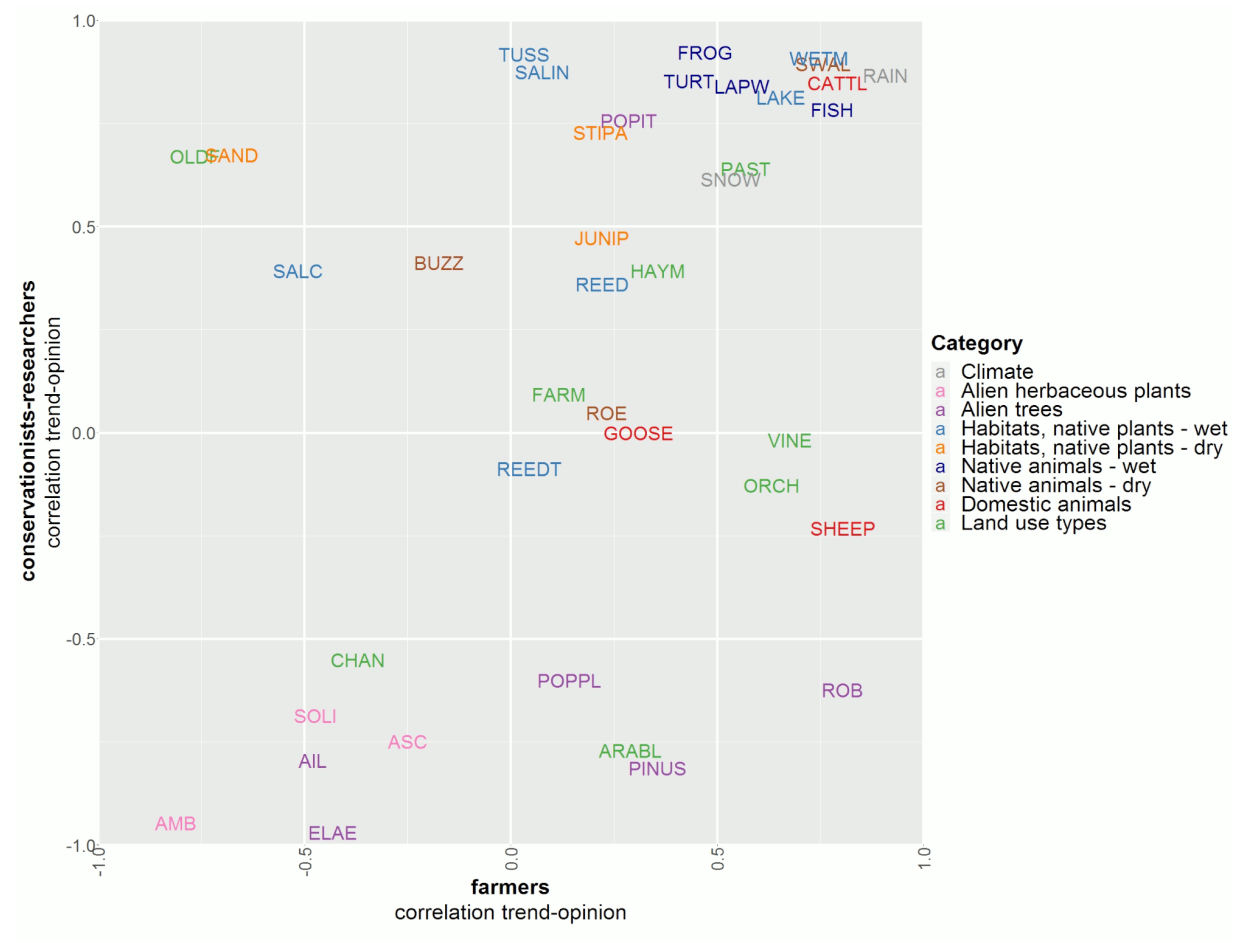

\section{Interconnectedness and experience}

The previous interview excerpts also exemplify the interconnectedness of the changes, and how the perception of the different processes in the landscape are linked and embedded in experiences and relations. While discussing the changes of tussocks with farmers, altogether 20 of the 40 landscape elements under examination were mentioned. The cattle's well-being was of evident importance, and many farmers described the tussocks through their perception of the cattle: "The cattle would only go around the top of where this was growing. They didn't like it much." The two groups narrated experiences related to the tussocky vegetation quite differently. Conservationistsresearchers recalled personal experiences much less frequently, e. g., botanical fieldworks. Farmers, however, often told stories about their activities managing the landscape, difficulties in movement, mowing, and grazing, the dangers for animals, and their memorable childhood experiences or the challenge of getting rid of the tussocks. "I know, because I was pulling up it," said one farmer.

\section{Conflicting perspectives}

Tussocks were perceived in the contested border zone of the nature-culture continuum, which implicated conflicting views among participants on the "wildness" of the tussocky areas. Many farmers pointed out that tussocky areas are wild places: "If cattle got away into it, they could make the sign of the cross over it in the old times. [The cattle would die.] But in my childhood, children going on a hike there was out of the question. Don't drown in it! This used to be a wetland, tussocks, so people couldn't go in." While other farmers emphasized the tended nature of the tussocky areas as well: "Whoever had such an area would mow it. Cut it off by hand mower," said a farmer. His wife explained, "It wasn't for feeding, but for bedding the cattle." The above mentioned farmer continued, "Every square meter had been taken care of back then."

Abandonment of land uses and loss of control over the processes were perceived negatively by farmers: "These territories sooner or later became impossible to cultivate because of the tussocks, or they could only be cultivated with very hard work later on. Now there are few, so it's not so hard; but when there are plenty of them, that's very hard." Therefore, control of land uses by nature conservation was an issue that some farmers also challenged: "Since the tussocks are gone now, well, people can use it. They could, if the national park allowed them to mow. But the national park doesn't allow mowing. Here the national park can only mow in late August because of the birds ... Well, meanwhile the bushes grow back inside." The increased water 
level at national park territories led to abandonment of previous cultivations, as a farmer explained: "Well here Lake Kolon was filled with water, because most of that territory used to be an arable land ... And now, you know, all of it is a nature conservation area. It's filled with water now."

Because of the loss of control over the cultural landscape, a couple of the farmers distanced themselves from the institution of nature conservation: "Of course, we ourselves are protecting nature very much. Nobody loves nature better than peasants." In contrast, the intensification caused by the agricultural subsidy system and its inconsistencies with the aim of conservation evoked negative feelings from some of the farmers: "That's annoying, because he [a farmer friend] can't get the subsidy, because his territory is like this ... and he can't clear it, and he has no cattle. He can't graze it and can't tidy it up. But, you know, many times he says that $10-20 \%$ of it [territory] must be kept as a place for the wild.”

\section{DISCUSSION}

\section{Perceptions of landscape change trends}

Our first research question concerned whether farmers and conservationists-researchers see the trends of the landscape changes differently. With a majority of the landscape elements, there was no significant difference (Fig. 1), which suggests that the studied landscape elements are salient and relevant to both groups and they both have detailed local knowledge of the area.

More interesting is to examine the small discrepancies both between and within the groups. One possible explanation for these differences might be the regional and temporal biases of perception. These could be past or present biases (Dallimer et al. 2009) or even time lags in perception (Bieling 2013), which can especially give rise to different perceptions of trends that change over time, e.g., cattle and old fields. The shifting baseline phenomenon (Soga and Gaston 2018) could also be observed, which may have caused discrepancies of data collected from younger and older interviewees. This was apparent in the case of tussock sedge beds, where, for example, many younger conservationists-researchers stated that their experience is limited to the last couple of decades, which were extremely dry. It may also serve as an explanation why the conservationist-researcher group assessed certain changes in landscape elements more mildly. The slightly greater consensus generally experienced among the conservationists-researchers could result from a type of bias of scale (Dallimer et al. 2009, Knapp and Fernandez-Gimenez 2009). As the case of tussocky habitat shows, many conservationistsresearchers made a comparison of the regional and local processes and gave a more generalized answer, compared to the more localized histories in the farmers' narratives. However, a territorial bias is also apparent because conservationists-researchers focused more on the changes within protected areas, compared to farmers who were mostly concerned with the processes related to cultivated lands around.

The other possible explanation of the differences between interviewees and stakeholder groups could be the local differences in dynamically changing landscape. The landscape element trends that showed the least consensus (vineyards, old fields, cattle, and reeds; see Table A1.1) may have proved controversial because their trends were influenced by policy-induced fluctuations of agricultural abandonment and intensification, e.g., abandonment linked to the political regime shift at the end of the 20th century, as well as both abandonment and intensification linked to EU agricultural policies (see also Bezák and Mitchley 2014, Jepsen et al. 2015, Mihók et al. 2017). The example of tussocky habitats shows how changes in landscape elements were determined by multiple interacting factors, but with different outcomes at the local level. Local changes in the landscape, like water retention supported by nature conservation, may also occur in opposition to regionally dominant trends of serious groundwater decline and loss of wetlands. Moreover, abandonment and intensification of uses influenced the shifting borders between "wild" areas with tussocks and "tidy" pastures and meadows. For tussock sedge beds, these anthropogenic causes, whether they are direct uses (grazing, mowing, and clearing with machines) or indirect causes like the effect of agricultural subsidy systems, were much more noticeable for farmers than conservationists-researchers.

\section{Competing views on productivity, biodiversity conservation, and landscape stewardship}

Our second research question concerned whether the farmers and conservationists-researcher valued landscape elements and their changes differently. Compared to the similar perception of trends, there were significant differences in the evaluation of landscape changes between the two groups (Fig. 4). The different evaluations manifest most strongly when there are changes in landscape elements that are either low in productivity yet high in natural value (sand dunes), high in regeneration potential (old fields) or high in productivity and low in natural value (plantations and arable fields). This discrepancy reflects that, for farmers, cultivation represents an important value. The case of tussocky habitats also highlights the importance of utility in how the farmers perceive the changes. This also reflects that the cause of these discrepancies should most likely be sought in the dissimilarities between farmers and conservationists-researchers in terms of their worldviews, identities, and relationships to the environment (Bennett 2016). Our results used landscapes, and the instrumental values of nature have a cultural significance for farmers, insofar as the land's usefulness and cultivation are integral to their identity as a good farmer (Burton 2004, Boonstra et al. 2011). Clearly intrinsic values of nature, however, were exceptionally rare among farmers, according to the qualitative analysis of the perception of tussocks. On the contrary, expansion of wild areas and the limited usability evoked a kind of resistance and an identity opposed to or in competition with that of nature conservationists (see also Boonstra et al. 2011, Kovács et al. 2015). For many farmers, this process was seen as a loss of control over processes within a changing network of power relations among different actors (see also Raymond et al. 2019). This could give us a new approach to viewing other processes on the natureculture continuum. For example, for farmers in our study, perception of a planted and economically valuable invasive alien species, e.g., Robinia, was much more positive than that of a spontaneously spreading alien species with no instrumental value, e.g., Ailanthus (see also García-Llorente et al. 2008, Rai et al. 2012). However, farmers perceived uncontrolled spreading as a problem not just in cases of alien plants, e.g., Asclepias and Elaeagnus, but also in terms of native species such as the spread of wild boars (see also Storie and Bell 2017) or encroachment by native shrubs (see also Bieling 2013) like Salix cinerea (Fig. 3). Therefore, a decline in utilitarian values and the sense of a loss 
of control over an area could be more important for farmers than the intrinsic distinction between nativeness and non-nativeness (see also Hobbs 2016).

Nevertheless, differences were much smaller between the two groups where the conservationists-researchers' more intrinsic environmental values were consistent with those of farmers' instrumental or relational values (Fig. 5). For both groups, extensive cattle farming and the use of grasslands as pastures and hay meadows were positive, which nowadays are accepted as important management methods of species-rich grasslands in the region (Vadász et al 2016). By contrast, the spread of invasive plants, drought in the region, and spontaneous encroachment were similarly seen as problems. For farmers, the loss of tussocks was important despite the fact that they are not really valuable or useful. Therefore, the tussock itself was not the object of value, but it attained new importance for them as an indicator of the regional water crisis (Kenter et al. 2019), which is of crucial priority to them according to previous studies as well (Kelemen 2013, Blanka et al. 2017). Farmers strongly identified as stewards of landscapes. In many cases, farmers represented themselves as using the land while living with nature, exemplifying how strongly their evaluations of nature were related to them. Building on the points of agreements, landscape stewardship identities and relational values of nature to farmers could be vital for future cooperation between the stakeholders with diverse knowledge and values (Berkes 2004, Díaz et al. 2015).

\section{Value-heterogeneity, shared values, and relationality}

Our third research question was aimed at examining whether farmers and conservationists-researchers differ in their valueheterogeneity. Other studies have already analyzed the heterogeneity of farmers' attitudes (Herzon and Mikk 2007, Kelemen et al. 2013); however, they do not contrast the farmers' heterogeneity with nature conservationists-researchers. Based on our quantitative results, opinions formed by farmers regarding landscape change showed much more heterogeneity, while conservationists-researchers made up a community of more uniform valuations. Values for consensus on evaluation were much higher within the conservationist-researcher group (Table A1.1). Their answers as plotted on the NMDS figure were denser, and the trend-opinion correlation was also stronger for them (Figs. 2 and 5). The tussocky habitat, the chosen landscape element for the qualitative analysis, was the most heterogeneously valued landscape element among farmers, both concerning the consensus values and the trend-opinion correlation. This corresponds with the literature about highly ambivalent perceptions of wetlands (Sherren and Verstraten 2013, Byg et al. 2017). The qualitative analysis of tussock sedge beds could provide useful insights for interpreting the quantitative results as well. Farmers much more frequently recalled their personal memories with tussock and activities on the land. Their evaluations were based more upon a tacit knowledge and experience, as well as their embedded connections to the landscape. It is also clear from the interviews how farmers personally discussed and weighed some competing approaches to long-term stewardship, productivity, and conserving biodiversity. Compared to the farmers' more contextual and individual values, conservationists-researchers have more shared values (Kenter et al. 2019). Even though conservationists-researchers had disagreements about how landscape change influenced biodiversity, the biodiversity itself was a core and unquestioned value for them. Thus relationalities of value formation are different for the two examined groups, which would explain why conservationists-researchers' values are more explicit, as opposed to the farmers' implicit values, which seemed to be less defined by previously examined evaluations of nature in literature (Burgess et al. 2000, Morris 2010, Raymond et al. 2010, Himes and Muraca 2018). Taking into account these diverse relationalities as they pertain to environmental values could be of indispensable importance, in order to bridge the gap between scientific and local knowledge (Raymond et al. 2010).

\section{Limitations and further steps}

An important finding of our study is that farmers had less consensus, and less shared views than conservationistsresearchers. However, further studies are needed to explore whether this can be explained by the different knowledge producing and sharing practices of farmers and conservationistsresearchers (Prell et al. 2010, Raymond et al. 2010). We speculate that farmers tend to be connected by more informal relationships as private individuals. The knowledge of conservationistsresearchers seemed more codified, presumably as they have more formalized relationships, and they discuss the landscapes' values and problems in more institutionalized ways (Morris 2010, Raymond et al. 2010). These kind of issues could be examined with more specific interview questions about ways of knowing, learning, and communicating within and between groups, as well as conducting qualitative participatory ethnographic research. With a larger group of interviewees, quantitative analysis could provide even more information about the influence of social factors of perception like age, gender, and farm size in terms of landscape perception's heterogeneity. Our qualitative analysis of an exemplary landscape element could give important insight into the interpretation of perception and values of the two groups under examination. However, the generalization of these results to other landscape elements has its limits because of the contextdependency of landscape change perceptions.

\section{CONCLUSION}

Based on the quantitative results, farmers and conservationistsresearchers perceived the trends of the changes rather similarly, but they showed much more differences in how they evaluated these changes. The mostly evident differences between the groups were in the case of the low productivity/high nature value or high productivity/low nature value landscape elements. Farmers proved to be a more heterogeneous group especially in terms of their values, compared to the more convergent answers of conservationists-researchers. The qualitative analysis about the tussock sedge habitat provided insights into the differing perception on the edge of the nature-culture continuum. Farmers perceived changes in the landscape through their various activities and cultural values, deeply embedded in the local culturalhistorical contexts. Although changes in usefulness were central to their views, which were competing with more intrinsic notions of biodiversity conservation, the ecosystem had more of a relational value for them. They were also deeply concerned about the past and future of the landscape and possessed attitudes of landscape stewardship, different than conservationists'researchers'. Compared to the eco-centric values shared by conservationists-researchers, farmers heterogeneously evaluated landscape changes based on individual constellations of 
economic interest, cultural values, and their sense of responsibility for nature. Thus, perception of the tussock sedge beds is interconnected with other landscape change processes in the transforming of the socio-natural world.

Understanding various stakeholder groups' perceptions of landscape changes could serve as the basis for a landscape stewardship based on cooperation, as well as for sustainable landscape and conservation management in the future. The mixed quantitative and qualitative methodology of our study also provides a new and systematic insight to comprehend the differences between and among farmers and conservationistsresearchers and explores the reasons for farmers' value heterogeneity.

Responses to this article can be read online at: http://www.ecologyandsociety.org/issues/responses. php/11742

\section{Acknowledgments:}

This article is dedicated to the memory of Mária Szabó, who did not live to see its publication. We sincerely thank the farmers, nature conservationists, and researchers who participated in this study for the interviews and their precious time and cooperation. We are also grateful to local residents and employees of the Kiskunság National Park for their assistance. We thank Patrick Mullowney for the translation and English-language editing, and Victoria Wyllie de Echeverria for the proofreading of the manuscript. We thank the anonymous reviewers for their valuable comments. Thanks to colleagues at University of Nottingham and Thomas Thornton, Anna Varga, and many other colleagues for their insight into earlier phases of the research. This research was partly supported by the project of the National Research, Development and Innovation Office [grant number GINOP-2.3.2-15-2016-00019]. The first author's work was supported by the Doctoral School of Environmental Sciences and the Faculty of Sciences, Eötvös Loránd University, and recently she was employed on the project of the National Research, Development and Innovation Office [grant number GINOP-2.3.2-15-2016-00056]; many thanks for this and to Zoltán Szalai for his continuous support.

\section{Data Availability Statement:}

The data that support the findings of this study are available on request from the corresponding author, NU. The data are not publicly available because they contain information that could compromise the privacy of research participants.

\section{LITERATURE CITED}

Ahnström, J., J. Höckert, H. L. Bergeå, C. A. Francis, P. Skelton, and L. Hallgren. 2009. Farmers and nature conservation: What is known about attitudes, context factors and actions affecting conservation? Renewable Agriculture and Food Systems 24:38-47. https://doi.org/10.1017/S1742170508002391

Aistara, G. A. 2009. Maps from space: Latvian organic farmers negotiate their place in the European Union. Sociologia Ruralis 49(2):132-150. https://doi.org/10.1111/j.1467-9523.2009.00485.x
Antrop, M. 2005. Why landscapes of the past are important for the future. Landscape and Urban Planning 70:21-34. https://doi. org/10.1016/j.landurbplan.2003.10.002

Ariti, A. T., J. van Vliet, and P. H. Verburg. 2015. Land-use and land-cover changes in the Central Rift Valley of Ethiopia: assessment of perception and adaptation of stakeholders. Applied Geography 65:28-37. https://doi.org/10.1016/j.apgeog.2015.10.002

Babai, D., A. Tóth, I. Szentirmai, M. Biró, A. Máté, L. Demeter, M. Szépligeti, A. Varga, Á. Molnár, R. Kun, and Z. Molnár. 2015. Do conservation and agri-environmental regulations effectively support traditional small-scale farming in East-Central European cultural landscapes? Biodiversity and Conservation 24 (13):3305-3327. https://doi.org/10.1007/s10531-015-0971-Z

Bardsley, D. K., and G. Edwards-Jones. 2007. Invasive species policy and climate change: social perceptions of environmental change in the Mediterranean. Environmental Science and Policy 10:230-242. https://doi.org/10.1016/i.envsci.2006.12.002

Benjamin, K., A. Bouchard, and G. Domon. 2007. Abandoned farmlands as components of rural landscapes: an analysis of perceptions and representations. Landscape and Urban Planning 83:228-244. https://doi.org/10.1016/j.landurbplan.2007.04.009

Bennett, N. J. 2016. Using perceptions as evidence to improve conservation and environmental management. Conservation Biology 30:582-592. https://doi.org/10.1111/cobi.12681

Berkes, F. 2004. Rethinking community-based conservation. Conservation Biology 18:621-630. https://doi.org/10.1111/ j.1523-1739.2004.00077.x

Bezák, P., and J. Mitchley. 2014. Drivers of change in mountain farming in Slovakia: from socialist collectivisation to the Common Agricultural Policy. Regional Environmental Change 14:1343-1356. https://doi.org/10.1007/s10113-013-0580-x

Bieling, C. 2013. Perceiving and responding to gradual landscape change at the community level: insights from a case study on agricultural abandonment in the Black Forest, Germany. Ecology and Society 18(2):36. https://doi.org/10.5751/ES-05590-180236

Bihari, Z., G. Babolcsai, J. Bartholy, Z. Ferenczi, J. Gerhátné Kerényi, L. Haszpra, K. Homoki-Ujváry, T. Kovács, M. Lakatos, Á. Németh, R. Pongrácz, M. Putsay, P. Szabó, and G. Szépszó. 2018. Climate. Pages 58-65 in K. Kocsis, editor. National atlas of Hungary: natural environment. Hungarian Academy of Sciences, Research Centre for Astronomy and Earth Sciences, Budapest, Hungary. [online] URL: http://www.nemzetiatlasz.hu/MNA/2 en. $\underline{\text { html }}$

Biró, M. 2015. A Duna-Tisza közi tájak természeti értékei: A Homokhátság természeti képe az elmúlt évszázadokban. Pages 209-213 in A. Iványosi Szabó, editor. A Kiskunsági Nemzeti Park Igazgatóság negyven éve. Kiskunsági Nemzeti Park Igazgatóság, Kecskemét, Hungary.

Biró, C., M. Biró, and A. Máté. 2015b. A Turján-vidék és az Őrjeg természeti képe az elmúlt évszázadokban. Pages 160-167 in A. Iványosi Szabó, editor. A Kiskunsági Nemzeti Park Igazgatóság negyven éve. Kiskunsági Nemzeti Park Igazgatóság, Kecskemét, Hungary.

Biró, M., J. Bölöni, and Z. Molnár. 2018. Use of long-term data to evaluate loss and endangerment status of Natura 2000 habitats 
and effects of protected areas. Conservation Biology 32:660-671. https://doi.org/10.1111/cobi.13038

Biró, M., B. Czúcz, F. Horváth, A. Révész, B. Csatári, and Z. Molnár. 2013b. Drivers of grassland loss in Hungary during the post-socialist transformation (1987-1999). Landscape Ecology 28:789-803 https://doi.org/10.1007/s10980-012-9818-0

Biró, M., A. Iványosi Szabó, and Z. Molnár. 2015a. A DunaTisza köze tájtörténete. Pages 41-58 in A. Iványosi Szabó, editor. A Kiskunsági Nemzeti Park Igazgatóság negyven éve. Kiskunsági Nemzeti Park Igazgatóság, Kecskemét, Hungary.

Biró, M., Z. Molnár, D. Babai, A. Dénes, A. Fehér, S. Barta, L. Sáfián, K. Szabados, A. Kiš, L. Demeter, and K. Öllerer. 2019. Reviewing historical traditional knowledge for innovative conservation management: a re-evaluation of wetland grazing. Science of the Total Environment 666:1114-1125. https://doi. org/10.1016/j.scitotenv.2019.02.292

Biró, M., K. Szitár, F. Horváth, I. Bagi, and Z. Molnár. $2013 a$. Detection of long-term landscape changes and trajectories in a Pannonian sand region: comparing land-cover and habitat-based approaches at two spatial scales. Community Ecology 14:219-230. https://doi.org/10.1556/ComEc.14.2013.2.12

Blanka, V., Z. Ladányi, P. Szilassi, G. Sipos, A. Rácz, and J. Szatmári. 2017. Public perception on hydro-climatic extremes and water management related to environmental exposure, SE Hungary. Water Resources Management 31(5):1619-1634. https:// doi.org/10.1007/s11269-017-1603-Z

Boonstra, W. J., J. Ahnström, and L. Hallgren. 2011. Swedish farmers talking about nature - a study of the interrelations between farmers' values and the sociocultural notion of naturintresse. Sociologia Ruralis 51:420-435. https://doi. org/10.1111/j.1467-9523.2011.00547.x

Buijs, A. E., B. Pedroli, and Y. Luginbühl. 2006. From hiking through farmland to farming in a leisure landscape: changing social perceptions of the European landscape. Landscape Ecology 21:375-389. https://doi.org/10.1007/s10980-005-5223-2

Burgess, J., J. Clark, and C. M. Harrison. 2000. Knowledges in action: an actor network analysis of a wetland agri-environment scheme. Ecological Economics 35:119-132. https://doi.org/10.1016/ $\underline{\mathrm{S} 0921-8009(00) 00172-5}$

Bürgi, M., C. Bieling, K. von Hackwitz, T. Kizos, J. Lieskovský, M. G. Martín, S. McCarthy, M. Müller, H. Palang, T. Plieninger, and A. Printsmann. 2017. Processes and driving forces in changing cultural landscapes across Europe. Landscape Ecology 32:2097-2112. https://doi.org/10.1007/s10980-017-0513-Z

Burton, R. J. F. 2004. Seeing through the 'good farmer's' eyes: towards developing an understanding of the social symbolic value of 'productivist' behaviour. Sociologia Ruralis 44:195-215. https:// doi.org/10.1111/j.1467-9523.2004.00270.x

Byg, A., J. Martin-Ortega, K. Glenk, and P. Novo. 2017. Conservation in the face of ambivalent public perceptions - the case of peatlands as 'the good, the bad and the ugly.' Biological Conservation 206:181-189. https://doi.org/10.1016/j.biocon.2016.12.022

Carr, S., and J. Tait. 1991. Differences in the attitudes of farmers and conservationists and their implications. Journal of
Environmental Management 32:281-294. https://doi.org/10.1016/ $\underline{\mathrm{S} 0301-4797(05) 80058-1}$

Castleberry, A., and A. Nolen. 2018. Thematic analysis of qualitative research data: Is it as easy as it sounds? Currents in Pharmacy Teaching and Learning 10(6):807-815. https://doi. org/10.1016/j.cpt1.2018.03.019

Chan, K. M. A., P. Balvanera, K. Benessaiah, M. Chapman, S. Díaz, E. Gómez-Baggethun, R. Gould, N. Hannahs, K. Jax, S. Klain, G. W. Luck, B. Martín-López, B. Muraca, B. Norton, K. Ott, U. Pascual, T. Satterfield, M. Tadaki, J. Taggart, and N. Turner. 2016. Why protect nature? Rethinking values and the environment. Proceedings of the National Academy of Sciences 113:1462-1465. https://doi.org/10.1073/pnas. 1525002113

Csorba, P., S. Ádám, Z. Bartos-Elekes, T. Bata, Á. Bede-Fazekas, B. Czúcz, P. Csima, G. Csüllög, N. Fodor, S. Frisnyák, G. Horváth, G. Illés, G. Kiss, K. Kocsis, L. Kollányi, É. Konkoly-Gyuró, N. Lepesi, D. Lóczy, Á. Malatinszky, G. Mezősi, G. Mikesy, Z. Molnár, L. Pásztor, I. Somodi, S. Szegedi, P. Szilassi, L. Tamás, Á. Tirászi, M. Vasvári. 2018. Landscapes. Pages 112-129 in K. Kocsis, editor. National atlas of Hungary: natural environment. Hungarian Academy of Sciences, Research Centre for Astronomy and Earth Sciences, Budapest, Hungary. [online] URL: http:// www.nemzetiatlasz.hu/MNA/2 en.html

Dallimer, M., D. Tinch, S. Acs, N. Hanley, H. R. Southall, K. J. Gaston, and P. R. Armsworth. 2009. 100 years of change: examining agricultural trends, habitat change and stakeholder perceptions through the 20th century. Journal of Applied Ecology 46:334-343. https://doi.org/10.1111/j.1365-2664.2009.01619.x

de Snoo, G. R., I. Herzon, H. Staats, R. J. F. Burton, S. Schindler, J. van Dijk, A. M. Lokhorst, J. M. Bullock, M. Lobley, T. Wrbka, G. Schwarz, and C. J. M. Musters. 2013. Toward effective nature conservation on farmland: making farmers matter. Conservation Letters 6:66-72. https://doi.org/10.1111/j.1755-263X.2012.00296. $\underline{\mathrm{x}}$

Descola, P., and G. Pálsson. 1996. Introduction. Pages 1-21 in P. Descola and G. Pálsson, editors. Nature and society: anthropological perspectives. Taylor \& Francis, London, UK. https://doi.org/10.4324/9780203451069 chapter 1

Díaz, S., S. Demissew, C. Joly, W. M. Lonsdale, and A. Larigauderie. 2015. A Rosetta Stone for nature's benefits to people. PLoS Biology 13(1):e1002040. https://doi.org/10.1371/ journal.pbio. 1002040

Dorondel, S. 2012. Neoliberal transformations of the Romanian agrarian landscape. Pages 13-22 in U. Münster, D. Münster, and S. Dorondel, editors. Fields and forests. Ethnographic perspectives on environmental globalization. RCC Perspectives 5. Rachel Carson Center for Environment and Society, Munich, Germany. https://doi.org/10.5282/rcc/6154

García-Llorente, M., B. Martín-López, J. A. González, P. Alcorlo, and C. Montes. 2008. Social perceptions of the impacts and benefits of invasive alien species: implications for management. Biological Conservation 141:2969-2983. https://doi.org/10.1016/j. biocon.2008.09.003

Gray, J. 2014. Hefting onto place: intersecting lives of humans and sheep on Scottish Hills landscape. Anthrozoös 27(2):219-234. https://doi.org/10.2752/175303714X13903827487520 
Harrell, F. E. 2018. Hmisc: Harrell miscellaneous. R package version 4.1-1. [online] URL: https://cran.r-project.org/web/ packages/Hmisc/index.html

Herrmann, S. M., I. Sall, and O. Sy. 2014. People and pixels in the Sahel: a study linking coarse-resolution remote sensing observations to land users' perceptions of their changing environment in Senegal. Ecology and Society 19(3):29. https://doi. org/10.5751/ES-06710-190329

Herzon, I., and M. Mikk. 2007. Farmers' perceptions of biodiversity and their willingness to enhance it through agrienvironment schemes: a comparative study from Estonia and Finland. Journal for Nature Conservation 15:10-25. https://doi. org/10.1016/j.jnc.2006.08.001

Himes, A., and B. Muraca. 2018. Relational values: the key to pluralistic valuation of ecosystem services. Current Opinion in Environmental Sustainability 35:1-7. https://doi.org/10.1016/j. cosust.2018.09.005

Hobbs, R. J. 2016. Degraded or just different? Perceptions and value judgements in restoration decisions. Restoration Ecology 24:153-158. https://doi.org/10.1111/rec.12336

Ingold, T. 2000. The perception of the environment: essays on livelihood, dwelling and skill. Routledge, London, UK. https://doi. org/10.4324/9780203466025

Ispán, Á. L., D. Babai, L. Mód, V. Ulicsni, and C. Mészáros. 2018. Complex ethnographic research methods for the study of protected areas and border communities at the SlovenianHungarian Border. Acta Ethnographica Hungarica 63(2):471-500. https://doi.org/10.1556/022.2018.63.2.12

Iványosi Szabó, A. 2015. Ahogy elkezdődött-a természetvédelem előzményei a Duna-Tisza közén. Pages 11-15 in A. Iványosi Szabó, editor. A Kiskunsági Nemzeti Park Igazgatóság negyven éve. Kiskunsági Nemzeti Park Igazgatóság, Kecskemét, Hungary.

Jepsen, M. R., T. Kuemmerle, D. Müller, K. Erb, P. H. Verburg, H. Haberl, J. P. Vesterager, M. Andrič, M. Antrop, G. Austrheim, I. Björn, A. Bondeau, M. Bürgi, J. Bryson, G. Caspar, L. F. Cassar, E. Conrad, P. Chromý, V. Daugirdas, V. Van Eetvelde, R. ElenaRosselló, U. Gimmi, Z. Izakovicova, V. Jančák, U. Jansson, D. Kladnik, J. Kozak, E. Konkoly-Gyuró, F. Krausmann, Ü. Mander, J. McDonagh, J. Pärn, M. Niedertscheider, O. Nikodemus, K. Ostapowicz, M. Pérez-Soba, T. Pinto-Correia, G. Ribokas, M. Rounsevell, D. Schistou, C. Schmit, T. S. Terkenli, A. M. Tretvik, P. Trzepacz, A. Vadineanu, A. Walz, E. Zhllima, and A. Reenberg. 2015. Transitions in European landmanagement regimes between 1800 and 2010. Land Use Policy 49:53-64. https://doi.org/10.1016/j.landusepol.2015.07.003

Junge, X., P. Lindemann-Matthies, M. Hunziker, and B. Schüpbach. 2011. Aesthetic preferences of non-farmers and farmers for different land-use types and proportions of ecological compensation areas in the Swiss lowlands. Biological Conservation 144:1430-1440. https://doi.org/10.1016/j.biocon.2011.01.012

Kelemen, E. 2013. Az Ökoszisztéma Szolgáltatások Közösségi Részvételen Alapuló, Ökológiai Közgazdaságtani Értékelése. Dissertation. Szent István University, Gödöllő, Hungary. [online] URL: https://szie.hu/file/tti/archivum/Kelemen_Eszter_PhD.pdf
Kelemen, E., G. Nguyen, T. Gomiero, E. Kovács, J.-P. Choisis, N. Choisis, M. G. Paoletti, L. Podmaniczky, J. Ryschawy, J.-P. Sarthou, F. Herzog, P. Dennis, and K. Balázs. 2013. Farmers' perceptions of biodiversity: lessons from a discourse-based deliberative valuation study. Land Use Policy 35:318-328. https:// doi.org/10.1016/j.landusepol.2013.06.005

Kennedy, B. L., and R. Thornburg. 2018. Deduction, induction, and abduction. Pages 49-64 in U. Flick, editor. The SAGE handbook of qualitative data collection. SAGE, London, UK. https://doi.org/10.4135/9781526416070.n4

Kenter, J. O., C. M. Raymond, C. J. van Riper, E. Azzopardi, M. R. Brear, F. Calcagni, I. Christie, M. Christie, A. Fordham, R. K. Gould, C. D. Ives, A. P. Hejnowicz, R. Gunton, A. I. HorceaMilcu, D. Kendal, J. Kronenberg, J. R. Massenberg, S. O'Connor, N. Ravenscroft, A. Rawluk, I. J. Raymond, J. Rodríguez-Morales, and S. Thankappan. 2019. Loving the mess: navigating diversity and conflict in social values for sustainability. Sustainability Science 14(5):1439-1461. https://doi.org/10.1007/s11625-019-00726-4

Knapp, C. N., and M. E. Fernandez-Gimenez. 2009. Knowledge in practice: documenting rancher local knowledge in Northwest Colorado. Rangeland Ecology and Management 62:500-509. https://doi.org/10.2111/08-175.1

Kohán, B., and J. Szalai. 2014. Spatial analysis of groundwater level monitoring network in the Danube-Tisza Interfluve using semivariograms. Hungarian Geographical Bulletin 63(4):379-400. https://doi.org/10.15201/hungeobull.63.4.2

Kovács, E., E. Kelemen, Á. Kalóczkai, K. Margóczi, G. Pataki, J. Gébert, G. Málovics, B. Balázs, Á. Roboz, E. Krasznai Kovács, and B. Mihók. 2015. Understanding the links between ecosystem service trade-offs and conflicts in protected areas. Ecosystem Services 12:117-127. https://doi.org/10.1016/j.ecoser.2014.09.012

Kuemmerle, T., C. Levers, K. Erb, S. Estel, M. R. Jepsen, D. Müller, C. Plutzar, J. Stürck, P. J. Verkerk, P. H. Verburg, and A. Reenberg. 2016. Hotspots of land use change in Europe. Environmental Research Letters 11(6):064020. https://doi. org/10.1088/1748-9326/11/6/064020

Lájer, K., A. Borhidi, Z. Molnár, J. Bölöni, A. Máte, and B. Lesku. 2011. B4 - Lápi zsombékosok, zsombék-semlyék komplexek. Tussock sedge communities. Pages 54-59 in J. Bölöni, Z. Molnár, and A. Kun, editors. Magyarország Élőhelyei. A Hazai Vegetációtípusok Leírása és Határozója. ÁNÉR 2011. MTA ÖBKI, Vácrátót, Hungary.

Latour, B. 1993. We have never been modern. Harvard University Press, Cambridge, Massachusetts, USA.

Mashi, S. A., and H. S. Shuaibu. 2018. People and sustainable land management: assessment of stakeholders knowledge of the nature of landuse/cover change in Abuja, Nigeria. GeoJournal 83:545-562. https://doi.org/10.1007/s10708-017-9782-y

Mbow, C., O. Mertz, A. Diouf, K. Rasmussen, and A. Reenberg. 2008. The history of environmental change and adaptation in eastern Saloum-Senegal-driving forces and perceptions. Global Planetary Change 64:210-221. https://doi.org/10.1016/j. gloplacha.2008.09.008

Mihók, B., M. Biró, Z. Molnár, E. Kovács, J. Bölöni, T. Erős, T. Standovár, P. Török, G. Csorba, K. Margóczi, and A. Báldi. 2017. 
Biodiversity on the waves of history: conservation in a changing social and institutional environment in Hungary, a post-soviet EU member state. Biological Conservation 211:67-75. https://doi. org/10.1016/j.biocon.2017.05.005

Molnár, Z., J. Kis, C. Vadász, L. Papp, I. Sándor, S. Béres, G. Sinka, and A. Varga. 2016. Common and conflicting objectives and practices of herders and conservation managers: the need for a conservation herder. Ecosystem Health and Sustainability 2: e01215. https://doi.org/10.1002/ehs2.1215

Morris, C. 2010. Environmental knowledge and small-scale rural landholding in south-west England. Geographical Journal 176:77-89. https://doi.org/10.1111/j.1475-4959.2009.00332.x

Muhar, A., C. M. Raymond, R. J. G. van den Born, N. Bauer, K. Böck, M. Braito, A. Buijs, C. Flint, W. T. de Groot, C. D. Ives, T. Mitrofanenko, T. Plieninger, C. Tucker, and C. J. van Riper. 2018. A model integrating social-cultural concepts of nature into frameworks of interaction between social and natural systems. Journal of Environmental Planning and Management 61 (5-6):756-777. https://doi.org/10.1080/09640568.2017.1327424

Münster, D., U. Münster, and S. Dorondel. 2012. Introduction. Pages 5-10 in U. Münster, D. Münster, and S. Dorondel, editors. Fields and forests. Ethnographic perspectives on environmental globalization. RCC Perspectives 5. Rachel Carson Center for Environment and Society, Munich, Germany. https://doi. org/10.5282/rcc/5595

Nakashima, D., K. G. McLean, H. D. Thulstrup, A. R. Castillo, and J. T. Rubis. 2012. Weathering uncertainty: traditional knowledge for climate change assessment and adaptation. UNESCO, Paris, France and United Nations University, Darwin, Australia. [online] URL: https://unesdoc.unesco.org/ark:/48223/ pf0000216613

Natori, Y., and R, Chenoweth. 2008. Differences in rural landscape perceptions and preferences between farmers and naturalists. Journal of Environmental Psychology 28(3):250-267. https://doi.org/10.1016/j.jenvp.2008.02.002

Newing, H. 2010. Conducting research in conservation: social science methods and practice. Routledge, London, UK. https:// doi.org/10.4324/9780203846452

Oksanen, J., F. G. Blanchet, R. Kindt, P. Legendre, P. R. Minchin, R. B. O'Hara, G. L. Simpson, P. Solymos, M. H. H. Stevens, and H. Wagner. 2016. vegan: Community ecology package. R package version 2.3-4. [online] URL: https://cran.r-project.org/web/ packages/vegan/index.html

Olwig, K. R. 1996. Recovering the substantive nature of landscape. Annals of the Association of American Geographers 86 (4):630-653. https://doi.org/10.1111/j.1467-8306.1996.tb01770.x

Pándi, I., K. Penksza, Z. Botta-Dukát, and G. Kröel-Dulay. 2014. People move but cultivated plants stay: abandoned farmsteads support the persistence and spread of alien plants. Biodiversity and Conservation 23:1289-1302. https://doi.org/10.1007/s10531-014-0665$\mathrm{y}$

Pásztor, L., E. Dobos, E. Michéli, G. Várallyay. 2018. Soils. Pages 82-93 in K. Kocsis, editor. National atlas of Hungary: natural environment. Hungarian Academy of Sciences, Research Centre for Astronomy and Earth Sciences, Budapest, Hungary. [online] URL: http://www.nemzetiatlasz.hu/MNA/2 en.html

Plieninger, T., and C. Bieling. 2012. Connecting cultural landscapes to resilience. Pages 3-26 in T. Plieninger and C. Bieling, editors. Resilience and the cultural landscape: understanding and managing change in human-shaped environments. Cambridge University Press, Cambridge, UK. https://doi.org/10.1017/ $\underline{\text { CBO9781139107778.003 }}$

Prell, C., M. Reed, L. Racin, and K. Hubacek. 2010. Competing structure, competing views: the role of formal and informal social structures in shaping stakeholder perceptions. Ecology and Society 15(4):34. https://doi.org/10.5751/ES-03652-150434

R Core Team. 2017. R: A language and environment for statistical computing. R Foundation For Statistical Computing, Vienna, Austria. [online] URL: https://www.r-project.org/

Rai, R. K., H. Scarborough, N. Subedi, and B. Lamichhane. 2012. Invasive plants - Do they devastate or diversify rural livelihoods? Rural farmers' perception of three invasive plants in Nepal. Journal for Nature Conservation 20:170-176. https://doi. org/10.1016/j.jnc.2012.01.003

Raymond, C. M., C. Bieling, N. Fagerholm, B. Martin-Lopez, and T. Plieninger. 2016. The farmer as a landscape steward: comparing local understandings of landscape stewardship, landscape values, and land management actions. Ambio 45:173-184. https://doi.org/10.1007/s13280-015-0694-0

Raymond, C. M., I. Fazey, M. S. Reed, L. C. Stringer, G. M. Robinson, and A. C. Evely. 2010. Integrating local and scientific knowledge for environmental management. Journal of Environmental Management 91:1766-1777. https://doi.org/10.1016/ j.jenvman.2010.03.023

Raymond, C. M., J. O. Kenter, C. J. van Riper, A. Rawluk, and D. Kendal. 2019. Editorial overview: theoretical traditions in social values for sustainability. Sustainability Science 14 (5):1173-1185. https://doi.org/10.1007/s11625-019-00723-7

Ruskule, A., O. Nikodemus, R. Kasparinskis, S. Bell, and I. Urtane. 2013. The perception of abandoned farmland by local people and experts: landscape value and perspectives on future land use. Landscape and Urban Planning 115:49-61. https://doi. org/10.1016/j.landurbplan.2013.03.012

Saldaña, J. 2013. The coding manual for qualitative researchers. SAGE, Los Angeles, California, USA.

Sayer, J., T. Sunderland, J. Ghazoul, J. L. Pfund, D. Sheil, E. Meijaard, M. Venter, A. K. Boedhihartono, M. Day, C. Garcia, C. van Oosten, and L. E. Buck. 2013. Ten principles for a landscape approach to reconciling agriculture, conservation, and other competing land uses. Proceedings of the National Academy of Sciences 110:8349-8356. https://doi.org/10.1073/pnas.1210595110

Schwartz, K. Z. S. 2006. "Masters in our native place": the politics of Latvian national parks on the road from communism to “Europe.” Political Geography 25(1):42-71. https://doi.org/10.1016/ j.polgeo.2005.07.001

Selman, P. 2012. Landscapes as integrating frameworks for human, environmental and policy processes. Pages 27-48 in $\mathrm{T}$. Plieninger, and C. Bieling, editors. Resilience and the cultural 
landscape: understanding and managing change in human-shaped environments. Cambridge University Press, Cambridge, UK. https://doi.org/10.1017/CBO9781139107778.004

Sherren, K., and C. Verstraten. 2013. What can photo-elicitation tell us about how maritime farmers perceive wetlands as climate changes? Wetlands 33:65-81. https://doi.org/10.1007/s13157-012-0352-2

Sipos, F. 2015. Természetvédelmi problémák a Turján-vidéken. Pages 189-194 in A. Iványosi Szabó, editor. A Kiskunsági Nemzeti Park Igazgatóság negyven éve. Kiskunsági Nemzeti Park Igazgatóság, Kecskemét, Hungary.

Soga, M., and K. J. Gaston. 2018. Shifting baseline syndrome: causes, consequences, and implications. Frontiers in Ecology and the Environment 16:222-230. https://doi.org/10.1002/fee.1794

Spearman, C. 1904. The proof and measurement of association between two things. American Journal of Psychology 15:72-101. http://dx.doi.org/10.2307/1412159

Stelling, F., C. Allan, and R. Thwaites. 2017. Nature strikes back or nature heals? Can perceptions of regrowth in a postagricultural landscape in south-eastern Australia be used in management interventions for biodiversity outcomes? Landscape and Urban Planning 158:202-210. https://doi.org/10.1016/j. landurbplan.2016.08.015

Storie, J. T., and S. Bell. 2017. Wildlife management conflicts in rural communities: a case-study of wild boar (Sus scrofa) management in Ērglu Novads, Latvia. Sociologia Ruralis 57:64-86. https://doi.org/10.1111/soru.12122

Szép, T., K. Nagy, Z. Nagy, and G. Halmos. 2012. Population trends of common breeding and wintering birds in Hungary, decline of long-distance migrant and farmland birds during 1999-2012. Ornis Hungarica 20:13-63. https://doi.org/10.2478/ orhu-2013-0007

Tastle, W. J., and M. J. Wierman. 2007. Consensus and dissention: a measure of ordinal dispersion. International Journal of Approximate Reasoning 45:531-545. https://doi.org/10.1016/j. ijar.2006.06.024

Ujházy, N., and M. Biró. 2013. A vizes élőhelyek változásai Szabadszállás határában. Tájökológiai Lapok 11:291-310.

Ujházy, N., and M. Biró. 2018. The 'Cursed Channel': utopian and dystopian imaginations of landscape transformation in twentieth-century Hungary. Journal of Historical Geography 61:1-13. https://doi.org/10.1016/j.jhg.2018.01.001

Vadász, C., A. Máté, R. Kun, and V. Vadász-Besnyői. 2016. Quantifying the diversifying potential of conservation management systems: an evidence-based conceptual model for managing species-rich grasslands. Agriculture, Ecosystems and Environment 234:134-141. https://doi.org/10.1016/j.agee.2016.03.044

Varga, A., and Z. Molnár. 2014. The role of traditional ecological knowledge in managing wood-pastures. Pages 185-202 in $\mathrm{T}$. Hartel and T. Plieninger, editors. European wood-pastures in transition: a social-ecological approach. Routledge, London, UK.

Wickham, H. 2009. ggplot2: Elegant graphics for data analysis. Springer-Verlag, New York, New York, USA.
Wickham, H. 2017. scales: Scale functions for visualization. R package version 0.5.0. [online] URL: https://cran.r-project.org/ web/packages/scales/index.html

Wickham, H., and L. Henry. 2018. tidyr: Easily tidy data with 'spread()' and 'gather()' functions. R package version 0.8.0. [online] URL: https://cran.r-project.org/web/packages/tidyr/ index.html

Widgren, M. 2012. Resilience thinking versus political ecology: understanding the dynamics of small-scale, labour-intensive farming landscapes. Pages 95-110 in T. Plieninger and C. Bieling, editors. Resilience and the cultural landscape: understanding and managing change in human-shaped environments. Cambridge University Press, Cambridge, UK. https://doi.org/10.1017/ CBO9781139107778.008 


\section{APPENDIX 1}

Table A1.1. Consensus values (Tastle and Wierman 2007) of the trend perceptions and evaluations according to farmers and conservationists-researchers.

\begin{tabular}{|c|c|c|c|c|}
\hline LANDSCAPE ELEMENTS & \multicolumn{2}{|c|}{$\begin{array}{l}\text { TRENDS } \\
\text { conservationists- } \\
\text { researchers } \\
\end{array}$} & \multicolumn{2}{|c|}{\begin{tabular}{cc}
\multicolumn{2}{c}{ EVALUATIONS } \\
$\begin{array}{c}\text { conservationists- } \\
\text { farmers }\end{array}$ \\
researchers
\end{tabular}} \\
\hline \multicolumn{5}{|l|}{ Land-use types } \\
\hline Arable field & 0.46 & 0.59 & 0.44 & 0.52 \\
\hline Vineyard & 0.32 & 0.43 & 0.54 & 0.32 \\
\hline Orchard & 0.35 & 0.58 & 0.62 & 0.20 \\
\hline Old field & 0.39 & 0.32 & 0.57 & 0.53 \\
\hline Channel & 0.66 & 0.72 & 0.36 & 0.32 \\
\hline Farm & 0.96 & 0.84 & 0.68 & 0.40 \\
\hline Hay meadow & 0.46 & 0.54 & 0.32 & 0.32 \\
\hline Pasture & 0.43 & 0.47 & 0.47 & 0.51 \\
\hline \multicolumn{5}{|l|}{ Domestic animals } \\
\hline Cattle & 0.32 & 0.41 & 0.68 & 0.70 \\
\hline Sheep & 0.33 & 0.63 & 0.59 & 0.30 \\
\hline Domestic goose & 0.69 & 0.69 & 0.57 & 0.67 \\
\hline \multicolumn{5}{|l|}{ Alien herbaceous plants } \\
\hline Ambrosia & 0.61 & 0.50 & 0.93 & 0.86 \\
\hline Asclepias & 0.78 & 0.56 & 0.44 & 1 \\
\hline Solidago & 0.59 & 0.69 & 0.38 & 0.85 \\
\hline \multicolumn{5}{|c|}{ Alien shrubs, trees and plantations } \\
\hline Robinia & 0.41 & 0.70 & 0.79 & 0.91 \\
\hline Ailanthus & 0.43 & 0.67 & 0.43 & 1 \\
\hline Elaeagnus & 0.52 & 0.58 & 0.42 & 1 \\
\hline Populus plantation & 0.67 & 0.51 & 0.32 & 0.58 \\
\hline Pinus plantation & 0.59 & 0.63 & 0.29 & 0.59 \\
\hline Populus n. 'Italica' & 0.74 & 0.73 & 0.64 & 0.59 \\
\hline \multicolumn{5}{|l|}{ Natural habitats and plants } \\
\hline \multicolumn{5}{|l|}{ Wet } \\
\hline Lake & 0.61 & 0.46 & 0.71 & 0.59 \\
\hline Wet meadow & 0.68 & 0.52 & 0.53 & 1 \\
\hline Tussock & 0.62 & 0.48 & 0.28 & 0.85 \\
\hline Saline land & 0.64 & 0.63 & 0.53 & 1 \\
\hline Reed bed & 0.39 & 0.47 & 0.35 & 0.04 \\
\hline Reed (thin) & 0.51 & 0.60 & 0.44 & 0.52 \\
\hline Salix cinerea & 0.51 & 0.65 & 0.42 & 0.26 \\
\hline \multicolumn{5}{|l|}{ Dry } \\
\hline Sand dune & 0.65 & 0.71 & 0.56 & 0.63 \\
\hline Stipa & 0.45 & 0.61 & 0.63 & 0.73 \\
\hline Juniperus & 0.47 & 0.53 & 0.56 & 0.33 \\
\hline \multicolumn{5}{|l|}{ Native animals } \\
\hline European pond turtle & 0.65 & 0.68 & 0.59 & 1 \\
\hline Lapwing & 0.73 & 0.64 & 0.67 & 1 \\
\hline Fish & 0.68 & 0.64 & 0.89 & 1 \\
\hline Frog & 0.63 & 0.64 & 0.55 & 1 \\
\hline Barn Swallow & 0.69 & 0.73 & 0.90 & 1 \\
\hline Buzzard & 0.43 & 0.69 & 0.43 & 0.48 \\
\hline Roe deer & 0.50 & 0.64 & 0.50 & 0.59 \\
\hline Wild boar & 0.76 & 0.91 & 0.64 & 1 \\
\hline \multicolumn{5}{|l|}{ Climate (precipitation) } \\
\hline Rain & 0.68 & 0.75 & 0.95 & 0.66 \\
\hline Snow & 0.80 & 0.84 & 0.73 & 1 \\
\hline
\end{tabular}

\section{Literature cited in Appendix 1}

Tastle, W. J., and M. J. Wierman. 2007. Consensus and dissention: A measure of ordinal dispersion. International Journal of Approximate Reasoning 45:531-545.

https://doi.org/10.1016/j.ijar.2006.06.024 